\title{
BUILDING REGULATORY PRACTICES IN 10 AFRICAN COUNTRIES IN THE FACE OF CLIMATE CHANGE
}

\author{
Gaum $\mathrm{T}^{*}$ and Laubscher $\mathbf{J}$ \\ Department of Architecture and Industrial Design, Tshwane University of Technology, South Africa
}

\begin{abstract}
The expected increase in building activities on the African continent and the anticipated future vulnerability of the continent in the face of climate change require investigation. This paper compares the building regulatory practices in 10 African countries to determine their responses to climate change. Various studies highlight the contribution of the built environment to total global greenhouse gas emissions, which mainly includes Water vapour $\left(\mathrm{H}_{2} \mathrm{O}\right)$, Carbon dioxide $\left(\mathrm{CO}_{2}\right)$, Methane $\left(\mathrm{CH}_{4}\right)$ and Nitrous oxide $\left(\mathrm{N}_{2} \mathrm{O}\right)$. Additionally, the relationship between greenhouse gas emissions, specifically $\mathrm{CO}_{2}$ and construction activities, is generally accepted due to increased energy use (IPCC, 2019). With just 10 years left, the United Nations Sustainable Development Goals are unlikely to be achieved by 2030. This exploratory study aims to establish whether the built environment of the 10 identified countries are currently taking any action towards the climate change effects and, if so, to determine their response and format. The paper reviews and compares present-day built environment regulatory policies on the African continent, focusing on energy efficiency measures. The results could be interpreted as a baseline when evaluating current policies, making the study beneficial to the selected countries and the broader African built environment. The study points towards a lack of building energy codes by the biggest emitters on the African continent. As part of the recommendations, African countries are encouraged to consider revising the regulatory documents governing the built environment to reduce greenhouse gas emissions on the continent.
\end{abstract}

Keywords: Building regulatory practices, climate change, greenhouse gas emissions, energy efficiency policies

\section{Introduction}

On a worldwide scale, communities are increasingly becoming more vulnerable to the effects of climate change. This is specifically true for the African continent where the report on the twenty-first session of the Conference of the Parties (COP 21) mentions "the vulnerability of the African continent as confirmed by United Nations resolutions and specialized bodies" (United Nations Framework Convention on Climate Change [UNFCCC], 2016). According to the Intergovernmental Panel on Climate Change (IPCC), the African continent has been identified as one of the most vulnerable when facing climate change. This is due to its geographic location and Africa is known as one of the hottest continents of the world. It is predicted to warm up to 1.5 times quicker than the global average (IPCC, 2014).

The IPCC further states that human activities are responsible for $95 \%$ of the increased greenhouse gas concentrations and that fossil fuel emissions are the primary source of emission due to Africa's 
growing population. The European Union and 179 other countries spent two weeks in Paris setting an agreement to possibly keep global temperatures below $2^{\circ} \mathrm{C}$. The COP 21 was one of the largest gatherings of world leaders and stated that the reduction in temperatures would only be possible by significantly reducing greenhouse gas emissions (COP 21 to the UNFCCC). In accordance with Article 21 of the Paris Agreement, the Parties to the Convention provided information on the most current total and percentage greenhouse gas emissions (UNFCCC, 2016, p. 30). Using the information provided in Annexure 1 of COP 21, the ten highest emitters on the African continent collectively contribute 77,30\% to the total African continent emissions of $2699024 \mathrm{Gg} \mathrm{CO}_{2}$ equivalent and 5,54\% to total world emissions (UNFCCC, 2016, pp. 30-34).

The Sustainable Cities Report states that:

"[t]here is a direct link between buildings and climate change due to the high rate of carbon emissions from the construction and ongoing use of buildings. Building resources take up to 40 per cent of energy use and 17 per cent of freshwater use. Twenty-five per cent of wood harvested and 40 per cent of material produced are attributed to the built environment." (De Lilly, 2009, p. 26).

The executive director of the United Nations Environment Programme (UNEP), Inger Andersen is of the opinion that a triple strategy is urgently needed to reduce the energy demand of buildings whereby emphasis needs to be placed on the rising emissions of the building and construction sector, specifically on the African continent (UNEP, 2020).

In 2008, the government first introduced the South African National Standard (SANS) 204: 2008 energy efficiency building regulations to lead the industry towards a more sustainable future slowly. In November 2011, the South African Bureau of Standards (SABS) and the National Regulator for Compulsory Specifications (NRCS) developed and implemented new building regulations known as the SANS 204: 2011 - Energy efficiency guidelines and the SANS 10400-XA: 2011 - The Application of the National Building Regulations, Part X: Environmental Sustainability and Part XA: Energy Usage in Buildings (Grove, 2013; SABS, 2011a; SABS, 2011b). These regulations aim to promote energy efficient design strategies in all new buildings, creating a more sustainable built environment.

In a lecture by Opperman (2011), senior technical advisor for Architecture and the National Building Regulations (NBR), he explains the impact of new regulations, stating that in the near future, a SANS $10400-\mathrm{XB}$ will cover water-efficiency in buildings and a SANS 10400-XC could cover the recycling of building materials. He is of the opinion that "the building industry can be part of the solution as huge amounts of energy will be saved if buildings are designed from the beginning to become more energy-efficient and environmentally-friendly" (Opperman, 2011). This research aims to shed light on the implementation status of building energy codes on the African continent, highlighting the lack of enforcement and the possibility of proposing best practice guidelines for further studies.

\section{Review of pertinent literature}

This literature review focuses on the regulatory framework of energy efficiency codes in the built environment of African countries. A detailed explanation of energy efficiency is presented with an overview of the relationship between building regulations and energy efficiency regulations. It is important to understand and highlight the differences as well as the advantages and disadvantages of 
energy efficiency codes versus standards building regulations. The literature review also serves as background to the article.

\section{Definition of Energy efficiency}

The concept of energy efficiency is widely used with many different associations and multiple definitions. In an attempt to formulate an appropriate definition for this study, the following definitions assist in providing a collective overview.

The International Energy Agency (IEA) focus is at the heart of global energy efficiency change and provides the following overall definition on energy efficiency:

"Energy efficiency is key to ensuring a safe, reliable, affordable and sustainable energy system for the future. It is the one energy resource that every country possesses in abundance and is the quickest and least costly way of addressing energy security, environmental and economic challenges." (IEA, 2016)

According to the Sustainable Buildings and Climate Initiative (SBCI) of the UNEP, the following definition of energy efficiency is accepted: "The energy efficiency of a building is determined by the rate at which energy is lost through the physical structure of the building (the building envelope), and the rate at which energy is used to meet the energy needs and physical comfort of the occupant." (UNEP SBCI, 2009, p. 23)

The SANS 204:2011 provides the most accurate definition on energy efficiency in relation to the built environment:

"Minimizing energy consumption while still achieving the required output. NOTE: In the context of buildings, this will be the maintenance of required indoor comfort conditions and the provision of necessary power for the correct operation of all installed services. Designing for energy efficiency involves the design, selection of materials, components and systems to minimize energy consumption. Achieving energy efficiency involves the design, operation, maintenance and ongoing adjustments to minimize energy consumption.” (SABS, 2011a, p. 5)

For this article, energy efficiency is defined as a sustainable energy system that meets the requirements for human comfort and energy usage while simultaneously minimising the energy outputs in order to maximise environmental sustainability.

\section{The relationship between building regulations and energy efficiency regulations}

Regulations governing the design and construction of buildings are generally referred to as building regulations or standards and are a set of functional guidelines that define how a new structure should be built to be structurally sound, address fire safety, be disabled friendly, amongst others.

According to Watermeyer (2003, p. 25) “...building standards have been in place since man was able to capture his thoughts in writing". Research indicates the oldest surviving building code could be traced back to circa 1780 BCE, during the reign of King Hammurabi in Mesopotamia (Cowan 1985, 
p. 27). This particular building code is grouped into different chapters with six sub-codes referring specifically to the built environment. The largest part of the code refers to a minimum standard that guarantees the safety of the structure; it could be argued that this represents the origin of contemporary building regulations (Laubscher 2011, p. 24).

Further research on the term provides the following descriptions. The Dictionary of Architecture and Building Construction by Davies and Jokiniemi (2008, pp. 52-53) provides the following overall definition for building regulations: "A statutory code which regulates the construction, alteration, maintenance, repair, and demolition of buildings and structures". In brief, the book entitled Building regulations provides the most concise description of the term building regulations: "A statutory instrument, which sets out the minimum requirements and performance standards for the design and construction of buildings, and extensions to buildings" (Tricker and Alger, 2006).

Building regulations can be seen as an official set of guidelines that has a technical point of reference in order to standardise the building and construction process by providing possible measurement criteria for buildings with the main objective of complying with a set of minimum requirements mostly for safety purposes.

\section{Energy efficiency regulations}

Energy efficiency regulations are a set of standards that prescribe the minimum energy performance for buildings or manufactured products. The term energy efficiency should not be confused with sustainability or "green buildings" where the criteria include renewable materials and embodied energy (Communities, 2010). Energy efficiency typically only focus on the energy usage and demand of a building. The vital role of energy codes and standards are to set out minimum requirements for energy efficient design and construction. Building energy codes specify the construction, performance and consumption of new buildings as well as additions, alterations and renovations. These codes can be implemented on a voluntary basis; however, they are mostly written in mandatory, enforceable language to describe the cost effective energy saving measures to significantly reduce overall built environment energy consumption (Bartlett et al., 2003; Iwaro and Mwasha, 2010, p. 3).

Although energy efficient building design and construction are quickly emerging as one of the mitigating factors of climate change, the growth in population, enhanced comfort levels, increase in building servicers together with the rise in time spent indoors will continue to increase the energy demand in future. The rapid growth of global energy use is raising concern about the supply of energy, the exhaustion of resources and severe environmental impacts, such as ozone layer depletion, climate change and global warming (Saidur, 2009; Iwaro and Mwasha, 2010, p. 4). In Africa, this situation is exacerbated, specifically in South Africa, where energy efficiency has become highly critical considering that projected electricity demand nearly equals the current production levels. Countries in Africa need to improve energy efficiency, introduce demand scheduling, and use alternative energies as strategies to effectively alleviate the problem and become more sustainable (Iwaro and Mwasha, 2010, p. 4).

A report by Liang et al. (2007) indicates the most cost effective way of reducing greenhouse gas emissions, specifically $\mathrm{CO}_{2}$, is the improvement of energy efficiency in new and existing buildings and ongoing construction. It is, therefore, one of the main objectives for policymakers today to 
introduce energy efficiency in buildings at regional, national and international levels (Saidur, 2009; Lombard et al., 2008).

In the context of the built environment, the Chartered Institution of Building Services Engineers (CIBSE) defines energy efficiency as the ability to facilitate and provide required internal comfort levels with minimum energy use in a cost effective and sustainable way (CIBSE, 2004). On 29 July 2005, the South African Department of Minerals and Energy report was published, entitled; Energy Efficiency: Energy and Demand Efficiency for Commercial Buildings. This report points out the typical definition of an energy efficient building by Asamoah, Dyer and Robilland (2005, p. 15) namely: "An energy efficient building provides the intended service, while at the same time minimizing/reducing the building's lifetime operating costs."

The researcher defines energy codes or standards as guidelines specifying the minimum requirements for design and construction in order to save energy as cost-effectively as possible. These regulations are written regulatory documents that the local government enforces and should be adopted in the design stage of buildings to possibly maximise the potential for the required "deemed-to-satisfy" energy consumption (Bartlett et al., 2003). While the use and implementation of building energy codes and standards exist in almost all developed countries, developing countries are slow to introduce such legislation (UNEP, 2009a, 2009b).

\section{Methodology}

The research initiated with a desk study, focusing on the pertinent regulatory building practices of ten African countries, their status and how the regulations and codes respond to the anticipated effects of climate change. Various authors indicate the validity of using desk research as an initiative method of exploring a theme (Andrews, Higgins, Andrews, Lalor, 2012; Smith, 2008; Smith et al., 2011).

The first part of this article serves as an introduction to the projected impacts of climate change, provides a brief overview of energy efficiency in the built environment and the importance of energy regulations in buildings. This is followed by providing a comprehensive definition of energy efficiency to establish the possible relationship between building regulations and energy efficiency regulations. Although large portions of secondary data is used within this study, it is of paramount importance to the article in order to review the current energy efficiency policies of the ten African countries

The second part of this article serves as a data gathering phase and focuses on identifying the top ten highest emitters of greenhouse gasses in Africa, establishing their current status of implementation and investigating their specific regulatory building practices and their response to climate change. This is achieved by investigating whether energy efficient building regulations are implemented in the selected African countries, followed by comparing the countries that implement energy efficiency regulations. Data gathering on the energy efficiency regulatory documents of the selected countries were collected through various official regulatory bodies, government departments or industry professionals, via email, phone and personal communication. The majority data sources used in this paper originate from the official regulatory bodies present within each country.

Due to the diversity of energy codes and the various implementation practices among countries, significant challenges arise in assessing the full impact of energy efficient building regulations on the 
African continent. This article concludes with discussions and recommendations on how the African built environment could address some challenges of climate change through the implementation of energy efficient building strategies or mechanisms.

\section{Results and discussion}

\section{Greenhouse gas emissions in Africa}

Research indicates that climate change is significantly impacted by countries with high $\mathrm{CO}_{2}$ emission rates. In the face of modest climate change targets in developing countries and recent reductions in some developed countries, future increase in emissions are inevitable due to continuous rise in $\mathrm{CO}_{2}$ emissions, GDP per capita development and projected growth in population figures (African Union [AU], 2015).

Current trends on population growth of the African continent has indicated a steady increase over the past ten years. According to the United Nations Department of Economic and Social Affairs (UNDESA), the African population is projected to double by the year 2050, reaching nearly 2,5 billion people. This significant increase in population figures will drive the need for future increase in energy demand and the related $\mathrm{CO}_{2}$ emissions (UNDESA, 2019).

Although Africa currently only contribute approximately 7,27\% to the total global $\mathrm{CO}_{2}$ emissions, the trajectory in which it is headed could significantly impact rising emission levels with certain African countries becoming bigger emitters that some of the developed countries. Thus, if the average growth rate of the African continent continues to rise as observed from 2010 to 2017, Africa's emissions will have risen nearly $30 \%$ by the year 2030 (Hamilton and Kelly, 2017). Rapidly growing cities located on the African continent are increasingly becoming more vulnerable to the effects of climate change, and the situation will amplify the existing social hurdles faced in high-populated cities with urban poverty (Alam and Rabbani, 2007).

The significance of the African continent is mainly supported by esteemed literature, scientific research, along with the correlation made between greenhouse gas emissions of the various continents and their emerging economic status, as displayed in Table 1 below. With the exception of Asia, the African continent emits the largest share of total greenhouse gas emissions compared to other developing continents.

Table 1: World total greenhouse gas contributors per continent

\begin{tabular}{lccc}
\hline Geographical region by continent & Economic status & $\begin{array}{c}\text { Emissions } \\
\left(\mathrm{Gg} \mathrm{Co}_{2} \text { equivalent }\right)\end{array}$ & $\begin{array}{c}\text { \% contribution to } \\
\text { total world emissions }\end{array}$ \\
\hline Asia & Developing & 15532675 & $41,87 \%$ \\
\hline North America & Developed & 8210230 & $22,07 \%$ \\
\hline Europe & Developed & 7945482 & $21,38 \%$ \\
\hline Africa & Developing & 2699024 & $7,27 \%$ \\
\hline South America & Developing & 2118503 & $5,7 \%$ \\
\hline Oceania \& Australia & Mixed & 632430 & $1,7 \%$ \\
\hline Total for the World & & & $100 \%$ \\
\hline
\end{tabular}


However, there are significant differences in emissions by countries in Africa. Beginning with South Africa contributing the largest share of greenhouse gas emissions $(20,40 \%)$ on the African continent and also currently ranking $12^{\text {th }}$ on the list of highest emitters in the world. Compared to a sizeable country such as the Democratic Republic of the Congo, contributing only 0,07\% and lastly to an island country, known as São Tomé and Príncipe, responsible for a mere 0,0037\% of the total African greenhouse gas emissions.

Therefore the next section focuses only on the ten highest emitters on the African continent to review their respective emission contributions in more detail.

\section{Ten highest greenhouse gas emitters in Africa}

The information gained from Article 21 of the Paris Agreement, Parties to the Convention and their national communicators provided information on the most up-to-date total and percentage of greenhouse gas emissions as of 12 December 2015. The researcher analysed the COP 21 agreement and listed the top 10 highest emitters of greenhouse gases in Africa accordingly. The top 10 respective contributions of the different African countries are listed in Table 2 below and represents the study target population.

Table 2: Top 10 greenhouse gas contributors of the different African countries.

\begin{tabular}{cccccc}
\hline No. & COP 21 Party & $\begin{array}{c}\text { Geographical } \\
\text { region }\end{array}$ & $\begin{array}{c}\text { Emissions } \\
\text { (Gg Co equivalent) }\end{array}$ & $\begin{array}{c}\text { \% contribution to } \\
\text { total world } \\
\text { emissions }\end{array}$ & $\begin{array}{c}\% \text { contribution to } \\
\text { total African } \\
\text { emissions }\end{array}$ \\
\hline 1 & South Africa & Southern Africa & 544314 & $1,46 \%$ & $20,41 \%$ \\
\hline 2 & Sierra Leone & Western Africa & 365107 & $0,98 \%$ & $13,69 \%$ \\
\hline 3 & Cote d'Ivoire & Western Africa & 271198 & $0,73 \%$ & $10,17 \%$ \\
\hline 4 & Nigeria & Western Africa & 212444 & $0,57 \%$ & $7,97 \%$ \\
\hline 5 & Egypt & Northern Africa & 193238 & $0,52 \%$ & $7,25 \%$ \\
\hline 6 & Cameroon & Middle Africa & 165725 & $0,45 \%$ & $6,22 \%$ \\
\hline 7 & Algeria & Northern Africa & 111023 & $0,30 \%$ & $4,16 \%$ \\
\hline 8 & Zimbabwe & Southern Africa & 68541 & $0,18 \%$ & $2,57 \%$ \\
\hline 9 & Sudan & Northern Africa & 67840 & $0,18 \%$ & $2,54 \%$ \\
\hline 10 & Angola & Middle Africa & 616111 & $0,17 \%$ & $2,31 \%$ \\
\hline \multicolumn{7}{c}{ Total top 10 African countries } & $5,54 \%$ & $77,30 \%$ \\
\hline & Other African countries (44) & $1,73 \%$ & $22,7 \%$ \\
\hline \multicolumn{7}{c}{ Total for Africa } \\
\hline
\end{tabular}

As seen above and stated earlier, the top 10 African countries collectively contribute a total of 77,30\% of the African continents greenhouse gas emissions and a total of $5.54 \%$ to the total world emissions (UNFCCC, 2016:30). The IPCC (2014) states that the primary source of fossil fuel emissions is largely attributed to Africa's growing population. This is concerning since the African continent is predicted to warm up to 1.5 times faster than other continents. The Department of Environmental Affairs (DEA) state that this could pose significant threats to water resources, vegetation, health and the infrastructure of African countries. It is suggested that urgent measures be implemented to help reduce the number of emissions produced annually (DEA, 2011). 
In the light of the current emissions extent of the top ten African emitters, it is necessary to study how their respective building regulations and codes respond to issues of climate change. After determining the population target for the study, research can commence on the current status, extent and implementation of the Building Energy codes and/or standards of the selected countries.

\section{Status of building regulatory practices in 10 African countries}

The table below identifies the specific countries regulatory building practices and whether they address climate change through energy efficiency policies. The primary focus is the enforcement of energy regulations in the specific regulatory building practices, however the possibility of some forms of passive solutions are also taken into consideration. Table 3 below compares the regulatory building practices in terms of energy efficiency regulations, passive solutions and enforcement by government.

Table 3: Status of Energy Efficiency Building Codes for the top 10 African countries.

\begin{tabular}{|c|c|c|c|c|c|c|}
\hline No & Country & $\begin{array}{c}\text { Energy Efficiency Building } \\
\text { Codes (EEBC) }\end{array}$ & Passive & $\begin{array}{l}\text { EEBC } \\
\text { Status }\end{array}$ & Mandatory & Enforced \\
\hline 1 & South Africa & $\begin{array}{l}\text { SANS 10400:2011 \& SANS } \\
\text { 204:2011 Energy Efficiency }\end{array}$ & $\checkmark$ & $\checkmark$ & $\checkmark$ & $\checkmark$ \\
\hline 2 & Sierra Leone & $\begin{array}{c}\text { The National Building Control } \\
\text { Regulations } 2015\end{array}$ & $\checkmark$ & - & - & - \\
\hline 3 & Cote d'Ivoire & Voluntary building regulations & - & - & - & - \\
\hline 4 & Nigeria & $\begin{array}{l}\text { National Building Energy } \\
\text { Efficiency Code } 2017\end{array}$ & $\checkmark$ & $\checkmark$ & $\checkmark$ & $\checkmark$ \\
\hline 5 & Egypt & $\begin{array}{l}\text { Residential Energy Efficiency } \\
\text { Building Code (EEBC)2006 }\end{array}$ & $\checkmark$ & $\checkmark$ & $\checkmark$ & \\
\hline 6 & Cameroon & None & - & - & - & - \\
\hline 7 & Algeria & $\begin{array}{c}\text { DTR C 3-2 - Thermal Building } \\
\text { Regulations }\end{array}$ & $\checkmark$ & $\checkmark$ & $\checkmark$ & $\checkmark$ \\
\hline 8 & Zimbabwe & Model Building By-Laws 1977 & - & - & - & - \\
\hline 9 & Sudan & $\begin{array}{l}\text { General Building Regulations } \\
2008\end{array}$ & $\checkmark$ & - & - & - \\
\hline 10 & Angola & None & - & - & - & - \\
\hline
\end{tabular}

After analysing the building regulatory practices of the 10 African countries, it is evident that 4 out of 10 countries $(40 \%)$ make provision for mandatory energy efficiency regulations. However, upon further investigation of the building energy codes, it is clear that the importance lies with the enforcement of regulations by local authorities and government to ensure effective implementation. It concerns that of the 10 countries, only 3 (30\%) of them enforce energy efficiency regulations and are working towards addressing climate change impact.

It is also perceived that although all countries do not implement extreme energy efficiency measures, 6 of the 10 countries implement some passive measures within their respective building regulatory practices. However, these passive solutions are insufficient in addressing the current climate change issues the African built environment faces. 
Table 3 established that there are 3 African countries, namely; South Africa, Algeria and Nigeria, enforcing energy efficiency building regulations. This result requires further research on the specific energy efficiency criteria present in each of the regulatory documents. The lack of building energy codes on the African continent is a major concern due to the high vulnerability and associated risks when facing climate change, particularly global warming.

\section{How the energy efficiency regulations are addressed}

After determining the current implementation status of the various African countries building regulatory practices and establishing whether they address climate change issues effectively, it is necessary to establish and understand how the energy efficiency building regulations of South Africa, Algeria, and Nigeria are addressed and implemented. The researcher will study the regulations of all 3 countries in depth to compare their specific requirements and solutions used to reduce energy consumption in the built environment.

\section{South Africa}

The SABS originally produced the NBR of South Africa as a set of guidelines for any person designing a building or structure to comply with specific minimum standards. In 2011, the release of the application of the NBR made provision for more sustainable buildings through the implementation of the SANS 204: 2011 - Energy efficiency guidelines and the SANS 10400-XA: 2011 - The Application of the National Building Regulations, Part X: Environmental Sustainability and Part XA: Energy Usage in Buildings (Grove, 2013; SABS, 2011a) by providing the 'deemed-to -satisfy' requirements to achieve the required level of energy efficiency (SABS, 2011b).

\section{SANS 204:2011 - Energy efficiency in buildings:}

"This standard specifies the design requirements for energy efficiency in buildings and of services in buildings with natural environmental control and artificial ventilation or air conditioning systems" (SABS, 2011a, p. 5).

\section{SANS 10400 XA - Energy usage in buildings:}

"Provides deemed-to-satisfy requirements for compliance with part XA (Energy Usage in Buildings) of the National Building Regulations" (SABS, 2011b, p. 5).

Part X: Environmental sustainability.

Part XA: Energy usage in buildings.

While the SANS 10400-XA: 2011 focuses on mandatory requirements for building approval, the SANS 204: 2011 is described as a partial copy comprising of voluntary standards with a higher requirement to achieve a green building rating. When implementing the energy efficiency regulations, it is important to understand that the positive effects of these regulations will also be dependable on the orientation of the building, shading, window sizing and positioning, insulation, solar heating, natural lighting and ventilation. 
Amanda Botes (2011), a senior manager, mentor and geographer at Urban Earth, believes that it is possible for building costs to increase as a result of the new energy efficiency regulations; however, it is certain to provide the built environment with a long term energy solution in a lower life cycle cost of buildings. This section of the NBR aims to decrease energy consumption in buildings, renovations, and alterations to contribute to environmental sustainability and assist with climate change issues.

\section{Algeria}

In Algeria, residential buildings are the main energy consumers, responsible for over $35 \%$ of the energy consumption (Chabane, 2010, p. 170). The development of the projected housing in Algeria and the use of air-conditioning systems, heating sources, and household appliances may lead to an exponential increase in energy usage consumption.

The Algerian Ministry of Habitat introduced the first energy efficiency programme that came into law in 2006, revised in 2011 and again in 2015. Algeria makes provision for energy saving and thermal efficiency in buildings through legal framework provided by the Centre National d' Etudes et de Recherches Intégrées du Bâtiment (CNERIB), known as the Document Technique Réglementaire (DTR). These technical regulatory documents are referred to as the Algerian Thermal Building Regulations and provide an overall response to the thermal problems and professional thermal evaluation methods for winter and summer conditions.

The Thermal Building Regulations for Residential buildings consist of two main parts. The first is relevant to winter, and the second relates to the summer period:

\section{DTR C3.2 - Rules for the Calorific Loss Calculation:}

"The purpose of this Regulatory Technical Document (DTR) is to establish methods for:

Determination of heat losses from buildings;

Verification of compliance of buildings with thermal regulations;

Dimensioning of heating installations for buildings; We introduce the notion of "Base" calorific losses;

Thermal design of buildings" (CNERIB, 2007, p. 10).

\section{DTR C3.4 - Calculation Rules for Calorific Buildings - Air Conditioning}

"The purpose of this Regulatory Technical Document (DTR) is to establish:

Methods for determining the heat inputs of buildings,

The method of verifying compliance with the summer thermal buildings" (CNERIB, 2005, p. 9).

To assist individuals with these complex documents a program has been developed by the Renewable Energy Development Centre, namely; RÉglementation Thermique Algérienne (RETA), meaning 
Software for Algerian Thermal Regulation. This program allows users to carry out the necessary thermal calculations and prevents errors as well as time-consuming calculations (Imessad, 2016). This tool will assist professionals with simulations while still in the design process in order to establish proper thermal performance before the construction phase commence.

While thermal building regulations and laws have been adopted in Algeria, the implementation of energy efficiency in buildings is mostly applied voluntarily. Despite great efforts from the Algerian Ministry, standards and regulations on the thermal performance of buildings are not enough to create more energy efficient and sustainable buildings. It is critical for countries to urgently address the lack of energy efficiency regulations, undertake long-term changes and provide enforceable sustainable solutions.

\section{Nigeria}

The Federal Government of Nigeria and the Federal Ministry of Power, Works and Housing (FMPWH) sector is responsible for ensuring adequate and sustainable housing, maintenance, and acceptable living conditions for all citizens. The National Building Code (NBC) development formed part of the objective to provide all the people of Nigeria with healthy, adequate and affordable housing within both urban and rural areas (FMPWH, 2006). The Nigerian NBC of 2006 is a set of guidelines referring to the general safety, fire protection and main structural systems and integrity of new buildings. These regulations do not address the requirements for energy efficiency and renewable energy systems.

In early 2015 the development of possible energy efficient building regulations started with comprehensive stakeholder involvement and relevant professionals in practice. Reaching out to relevant stakeholders and professionals in the built environment plays a vital role in the discussions around building permit use, availability of materials and characteristics of the Nigerian building stock to establish the requirements that energy efficiency regulations should fulfil in the future (FMPWH, 2017). Further workshops, discussions, and interviews with professional architects, engineers, developers, and builders also formed part of the building authority representatives. In finalising the proposed guidelines, international experts provided extensive support and technical expertise on sustainability and energy efficiency in the built environment. In 2017 the Government of Nigeria introduced their first official energy code, known as The National Building Energy Efficiency Code (BEEC) of Nigeria 2017.

\section{National BEEC of Nigeria 2017:}

"Building Energy Efficiency Code specifies minimum energy required to achieve energy efficient buildings which in turn impacts on the socio-economic wellbeing of citizens and country at large.

The energy efficiency code consist of the following elements:

- Minimum energy efficiency requirements and verification methods;

- Calculation methods and tools;

- Building energy label and energy efficiency incentives; 
- Control and enforcement;

- Qualification of experts;

- Review and adaptation." (FMPWH, 2017).

The BEEC of Nigeria 2017 aims to provide users with the minimum requirements to achieve energy efficiency in the built environment and ultimately ensure proper implementation, control, and enforcement.

The Honourable Minister of Power, Works and Housing, Babatunde Raji Fashola, Senior Advocate of Nigeria, gives a powerful statement on energy efficiency: "Conservation, waste reduction, and efficient energy use are critical contributors to increasing supply of energy, stabilizing the supply of energy and ensuring the unfailing supply of energy; because whatever is wasted will never be enough." (FMPWH, 2017).

However, Winkler (2006, p. 27), energy and climate policy researcher from the University of Cape Town, believes that without enforcement mechanisms, the implementation of regulations is not meaningful. Building energy codes, regulations and policies are widely implemented through voluntary associations or green rating systems in many countries, still only a few countries on the African continent enforce these codes.

The researcher believes that future building and construction processes have to be reviewed. Ideally, the construction of energy efficient buildings should be promoted, while the energy systems of existing buildings should focus on the reduction of $\mathrm{CO}_{2}$ and other greenhouse gas emissions.

\section{Comparison of selected building energy codes}

This section of the article presents the analysis and discussion of the findings from the study.

The researcher believes that future building and construction processes have to be reviewed. Ideally, the construction of energy efficient buildings should be promoted, while the energy systems of existing buildings should focus on the reduction of $\mathrm{CO}_{2}$ and other greenhouse gas emissions.

\section{Comparison of selected building energy codes}

This section of the article presents the analysis and discussion of the findings from the study.

Table 4 represents the building energy codes of South Africa, Algeria, and Nigeria and identifies the specific instruments used in their respective regulations to reduce the energy consumption in buildings. These energy efficiency regulations are analysed and compared in terms of the various passive and active measures available as well as the extent and specifics of energy efficiency measures implemented. Table 4 represents a summary of the information above and provides a comprehensive overview of the 3 countries that address energy efficiency by implementing building energy codes. 
Table 4: Comparison of minimum energy efficiency requirements for $S A$, Algeria and Nigeria regulations.

\begin{tabular}{|c|c|c|c|c|}
\hline Criteria & $\begin{array}{l}\text { South } \\
\text { Africa }\end{array}$ & Algeria & Nigeria & Notes \\
\hline Site Orientation & $\checkmark$ & $\checkmark$ & - & $\begin{array}{l}\text { South Africa focuses more on orientation of the sun. } \\
\text { Algeria focuses more on the condition of the soil and site. }\end{array}$ \\
\hline Climatic Zones & $\checkmark$ & $\checkmark$ & - & $\begin{array}{l}\text { South Africa has six climatic zones. } \\
\text { Algeria has four main climatic zones and two subfield zones. }\end{array}$ \\
\hline Heat loss & $\checkmark$ & $\checkmark$ & - & $\begin{array}{l}\text { Both South Africa and Algeria standards make reference to } \\
\text { thermal resistance, thermal transmittance and thermal capacity. } \\
\text { Nigeria only refers to thermal resistance within roof assemblies. }\end{array}$ \\
\hline Heat gain & $\checkmark$ & $\checkmark$ & - & $\begin{array}{l}\text { South Africa provides calculations of solar heat gain. } \\
\text { Algeria provides extensive calculations for heat input of } \\
\text { buildings. }\end{array}$ \\
\hline Thermal bridge & - & $\checkmark$ & - & $\begin{array}{l}\text { Algeria has extensive calculations on the losses through thermal } \\
\text { bridges. } \\
\text { South Africa and Nigeria does not specifically address thermal } \\
\text { bridging. }\end{array}$ \\
\hline Air leakage & $\checkmark$ & $\checkmark$ & - & $\begin{array}{l}\text { South Africa makes reference to ceiling voids, attics, glazing, } \\
\text { roof lights, chimneys, flues, skylights, external doors, exhaust } \\
\text { fans, roofs, walls and floors and sealing materials. } \\
\text { Algeria provides calculations for determining the air leakage in } \\
\text { buildings. }\end{array}$ \\
\hline $\begin{array}{l}\text { Thermal } \\
\text { Insulation }\end{array}$ & $\checkmark$ & $\checkmark$ & $\checkmark$ & $\begin{array}{l}\text { South Africa mentions floors, walls, roofs and hot water pipes. } \\
\text { Algeria use shutters and blinds as part of insulating the building } \\
\text { and have extensive calculations regarding the thermal } \\
\text { insulation of walls and floors. } \\
\text { Nigeria makes only reference to roof insulation }\end{array}$ \\
\hline Lighting & $\checkmark$ & - & $\checkmark$ & $\begin{array}{l}\text { South Africa provides tables with energy demands and } \\
\text { consumptions for lighting. } \\
\text { Nigeria maximum lighting power density } 6 \mathrm{~W} / \mathrm{m} 2 \text { for } \\
\text { residential and } 8 \mathrm{~W} / \mathrm{m} 2 \text { for offices. }\end{array}$ \\
\hline Power usage & $\checkmark$ & - & - & $\begin{array}{l}\text { South Africa provides tables with energy demand and } \\
\text { consumption of power usage. } \\
\text { Algeria only refers to heating power required for housing } \\
\text { appliance use. } \\
\text { Nigeria excludes the energy consumption of appliances, water } \\
\text { heating and consumption related to industrial processes. }\end{array}$ \\
\hline Fenestrations & $\checkmark$ & - & - & $\begin{array}{l}\text { South Africa provides for seven types of energy efficient } \\
\text { glazing. } \\
\text { Algeria provides for } 8 \text { types of normal glazing. }\end{array}$ \\
\hline $\begin{array}{l}\text { Hot water } \\
\text { services }\end{array}$ & $\checkmark$ & $\checkmark$ & - & $\begin{array}{l}\text { South Africa states that a minimum of } 50 \% \text { annual average hot } \\
\text { water heating requirement shall be provided by means other } \\
\text { than electrical resistance heating. } \\
\text { Algeria makes reference to water tanks, pipes and the related } \\
\text { temperatures. }\end{array}$ \\
\hline Shading & $\checkmark$ & - & $\checkmark$ & $\begin{array}{l}\text { South Africa has shading calculations to establish the glazing } \\
\text { needs, where shutters, blinds or screens should be capable of } \\
\text { restricting } 80 \% \text { of summer solar radiation. } \\
\text { Nigeria requires suitable shading where window-wall ratio } \\
\text { exceeds } 20 \% \text {. }\end{array}$ \\
\hline $\begin{array}{l}\text { Renewable /Solar } \\
\text { energy }\end{array}$ & $\checkmark$ & $\checkmark$ & - & $\begin{array}{l}\text { South Africa suggests that solar heating pumps are used to } \\
\text { assist with the } 50 \% \text { volume of hot water consumption. }\end{array}$ \\
\hline
\end{tabular}




\begin{tabular}{llll}
\hline Roof assemblies & $\checkmark$ & $\checkmark$ & $\begin{array}{l}\text { South Africa gives minimum R-value in the different climatic } \\
\text { zones for roof construction } 2.7 \mathrm{~m}^{2} \mathrm{~K} / \mathrm{W}-3,7 \mathrm{~m}^{2} \mathrm{~K} / \mathrm{W} . \\
\text { Nigeria gives thermal resistance of not less than } 1.25 \mathrm{~m}^{2} \mathrm{~K} / \mathrm{W} .\end{array}$ \\
\hline Passive solutions & $\checkmark$ & $\begin{array}{l}\text { South Africa and Algeria use natural lighting and ventilation as } \\
\text { passive solutions. }\end{array}$ \\
& $\checkmark$ & $\begin{array}{l}\text { Nigerian BEEC does not make mention of passive solutions, } \\
\text { however the NBC 2006 does include natural lighting and } \\
\text { ventilation. }\end{array}$ \\
\hline
\end{tabular}

Table 4 presents the current energy efficiency criteria as set out by the building energy codes of South Africa, Algeria and Nigeria whilst identifying possible research gaps and implementation strategies for the built environment. Analysing and discussing the result in Table 4, concludes that all three countries make some effort to provide energy efficiency and sustainability within the built environment.

When comparing the building energy codes of South Africa, Algeria and Nigeria it is clear that the SANS 10400-XA: 2011 provides for all the necessary energy efficiency criteria, with the exception of thermal bridge requirements. This could be due to the fact that the South African built environment is more developed than the rest of the developing countries in Africa and could ultimately be used as possible best practice guidelines.

Further investigation also reveals the Algerian DTR covers many of the energy efficiency criteria with the exception of lighting, power usage, fenestration and shading. The Algerian DTR is the only document of the three that addresses the importance of thermal bridging and places great emphasis on calculations specifically to determine the heat losses and gains. However, considering the aforementioned criteria not addressed in the current regulations, it is suggested that energy codes relating to shading and renewable solutions are investigated as these are major contributors in reducing built environment energy consumption.

Comparing the results of the energy efficiency criteria in the various regulations from Table 4 it is evident that the BEEC of Nigeria 2017 is currently not up to standard. According to the comparative data, the BEEC of Nigeria 2017 only address 5 of the 15 (33,33\%) set out energy efficiency criteria. This is concerning, seeing that current regulations are not addressing issues of orientation, insulation, renewable energy systems, heat gain and losses or other major contributors to energy consumption in the built environment. Even though great efforts from the Nigerian government is a step in the right direction, it is still not sufficient for meeting 2050 climate change targets and mitigating the impacts of climate change.

When making the aforementioned comparisons on the energy efficiency criteria of the countries it can concluded that the following criteria is most favourably implemented, namely: Thermal insulation, roof assemblies and forms of passive solutions. Although numerous energy efficiency topics are covered in these agreements, it is uncertain whether they are sufficient in establishing a greater climate change initiative. Similarly, these energy efficiency regulations lead countries towards a more sustainable built environment that addresses climate change and will assist professionals in the gradual implementation of green designs. 


\section{Conclusions and recommendations}

Building energy codes are essential mechanisms to obtaining a low-carbon footprint for achieving energy efficiency in the built environment; however, effective implementation systems are crucial to their success. Evaluating the effectiveness of building energy codes across countries can be executed in many ways, especially when policymakers recognise the need for stronger implementation frameworks. This creates a shift in emphasis to support the implementation and adaptation of existing regulations and achieve climate change targets in the building sector

This study analysed the building energy codes of 10 African countries, characterized by key elements of implementation and possible energy efficiency criteria. A review of the 10 practices reveals the significant differences in implementation policies across the countries. Only 3 African countries implement building energy codes. This paper compares the energy efficiency building regulations of South Africa, Algeria and Nigeria. Actual figures and values are difficult to compare seeing that geography and climatic regions will greatly influence these results. As a result of this, the focus of the three documents differ, and each one places emphasis on different energy efficiency criteria. This is due to the specific climatic region of each country, where it is evident that the use of solar energy is suggested in South Africa, yet the Algerian regulations make provisions for snow and wind calculations.

Although the regulatory documents are climate specific, it is still possible to compare some of the major energy efficiency criteria addressed and establish whether it is necessary to revise or improve current regulations and ultimately propose possible best practice guidelines. Based on the comparison of practices, it is evident that South Africa and Algeria address most of the same energy efficiency criteria, whereas the BEEC of Nigeria 2017 acts as a brief guideline covering only a few of the possible energy efficiency strategies available.

The South African energy code, SANS 10400-XA: 2011 contains various comprehensive energy efficiency criteria, including approval from the local authority for thermal compliance and fenestration calculations. South Africa has taken numerous steps to improve its energy regulations and support climate change initiatives in the built environment. Although the Algerian DTR covers a vast range of energy efficiency criteria, it is suggested that regulations be updated to include lighting design, fenestration calculations and possible shading requirements. These sustainability measures play a vital role in the reduction of building energy consumption and the overall efficiency of a building. Lastly, it should be noted that even though the BEEC of Nigeria 2017 is currently not up to standard when compared to other African countries, their efforts are to be recognised, seeing that only 3 out of $10(30 \%)$ selected countries are addressing issues of climate change through built environment regulatory practices. It is suggested that Nigeria look towards greater implementation and more detailed energy efficiency criteria, specifically the inclusion of orientation, climate zones, fenestration and thermal calculations regarding heat gains and losses in buildings.

The major concern is that although the above mentioned regulations provide for a wide range of alternative solutions, there are still bigger issues concerning climate change within the built environment. This paper proposes the need to urgently investigate the criteria of energy efficacy and identify the sustainability gaps in the built environment. It is recommended that countries that do not currently address energy efficiency within their building regulations should consider revising their 
respective documents and/or adopt possible best practice guidelines from the South African built environment. Building energy efficiency initiatives could eventually assist the whole of Africa in reducing its greenhouse gas emissions and mitigating the impacts of climate change.

This research aims to highlight the status, understanding and implementation of building regulatory practices on the African continent. It further emphasises the importance of building energy codes, the related benefits, reduction in emissions and ultimately the effective implementation by policymaker to a successful energy efficiency strategy.

\section{Future research studies}

The authors recommend that regulatory bodies, voluntary associations and government departments urgently address the need to develop, revise and adapt building energy efficiency codes and regulations. It is recommended that regular seminars and work sessions be held on this subject matter and aligned with climate change targets. It is further recommended that future studies look towards the probability of built environment sectors achieving 2050 climate change targets, undertaken in the Paris Agreement by individual governments and related stakeholders of each country. This could assist countries with the necessary information to adapt current climate change mitigation strategies and set them back on track to reach climate targets by 2050, thereby reducing $\mathrm{CO}_{2}$ emissions and ultimately creating a more sustainable environment.

\section{References}

Alam, M., \& Rabbani, G. (2007). Vulnerabilities and responses to climate change for Dhaka. Environment and Urbanization, 19, pp. 81-97.

Andrews, L., Higgins, A., Andrews, M. W., \& Lalor, J. G. (2012). Classic grounded theory to analyse secondary data: Reality and reflections. The Grounded Theory Review, 11(1), pp. 12-26.

Asamoah, J., Dyer, L. \& Robilland, P. (2005). Department of Minerals and Energy, Pretoria: Capacity Building in Energy Efficiency and Renewable Energy: Energy Efficiency: Energy and Demand Efficiency for Commercial Buildings - Draft Final Report: 29 July 2005. Pretoria: Department of Minerals and Energy Affairs.

AU. (2015). African Union Agenda 2063 2015. The Africa we want. African Union. [Online]. Available from: https://au.int/en/agenda2063/overview. [Accessed 30 June 2021].

Bartlett, R., Halverson, M.A., \& Shankle, D.L. (2003). Understanding Building Energy Codes and Standards. National Technical Information Service: Washington. 
Botes, A. (2011). Energy efficiency regulations for new buildings. Urban Earth 2015. [Online]. Available from: http://www.urbanearth.co.za/articles/energy-efficiency-regulations-newbuildings. [Accessed 13 June 2017].

Chabane, L. (2010). Contribution to the definition of an Energy Audit Procedure in Algeria's housing, master thesis, EPAU, 170 pp. [Online]. Available from: www.ons.dz. Algeria. [Accessed 20 April 2021].

CIBSE. (2004). Chartered Institution of Building Services Engineers. Energy efficiency in buildings: cibse guide. 2nd ed. London: CIBSE.

CNERIB. (2005). DTR C3.4 Règlement Thermique des Bâtiments d'Habitation - Règles de Calcul des Apports Calorifiques des Bâtiments: Fascicule 2, Document Technique Règlementaire Ministère de l'habitat et de l'urbanisme. Alger: CNERIB.

CNERIB. (2007). DTR C3.2 Règlement Thermique des Bâtiments d'Habitation - Règles de Calcul des Déperditions Calorifiques: Fascicule 1, Document Technique Règlementaire Ministère de l'habitat et de l'urbanisme. Alger: CNERIB.

Communities. (2010). Building regulation. [Online]. Available from: http://www.communities.gov.uk/documents/panningandbuilding/pdf/cited2010S. [Accessed 30 April 2021].

Cowan, H.J. (1985). The Master Builders: A history of structural and environmental design form Ancient Egypt to the Nineteenth century. Reprint Ed. New York: Wiley.

Davies, N., \& Jokiniemi, E. (2008). Dictionary of Architecture and Building Construction. 1st edn. Oxford: Architectural Press.

De Lilly, A., Editor. (2009). Sustainable Cities Report 2009. Braamfontein: South African Cities Network (SACN).

DEA. (2011). South Africa's Second National Communication under the United Nations Framework Convention on Climate Change. Pretoria, South Africa: Department of Environmental Affairs, Republic of South Africa (RSA).

FMPWH. (2006). The National Building Code of the Federal Republic of Nigeria. NBC, $1^{\text {st }}$ Edition. Lexis Nexis, Butterworths, South Africa [Online]. Available from: 
https://epp.lagosstate.gov.ng/regulations/National_Building_Code_of_Nigeria_2006.pdf. [Accessed 02 February 2021].

FMPWH. (2017). Federal Ministry of Power, Works and Housing: Building Energy Efficiency Code (BEEC). [Online]. Available from:

https://rise.esmap.org/data/files/library/nigeria/Energy\%20Efficiency/Supporting\%20Docume ntation/Nigeria_BEEC-National\%20Building\%20Energy\%20Efficiency\%20Code.pdf. [Accessed 20 November 2020].

Grove, T. (2013). SAFAL Steel. [Online]. Available from: http://safalsteel.co.za/2013/12/24/explained-sans-10400-sans-204-regulations/. [Accessed 01 March 2021].

Hamilton, T. G. A., \& Kelly, S. (2017). Low carbon energy scenarios for sub-Saharan Africa: an input-output analysis on the effects of universal energy access and economic growth. Energy Policy, 105, 303-19.

IEA. (2016). Energy Efficiency: Market Report 2016. Paris, France: International Energy Agency.

Imessad, K. (2016). RETA: Application software for Algerian Thermal Regulations: RETA- Logiciel d'application de la Réglementation Thermique Algérienne. Renewable Energy Development Centre. [Online]. Available from: https://www.cder.dz/spip.php?article2348. [Accessed 15 May 2021].

IPCC. (2014). Climate Change 2014: Mitigation of Climate Change. Contribution of Working Group III to the Fifth Assessment Report of the Intergovernmental Panel on Climate Change. Cambridge, UK: Cambridge University Press.

IPCC. (2019). Climate Change and Land: an IPCC special report on climate change, desertification, land degradation, sustainable land management, food security, and greenhouse gas fluxes in terrestrial ecosystems [P.R. Shukla, J. Skea, E. Calvo Buendia, V. Masson-Delmotte, H.-O. Pörtner, D. C. Roberts, P. Zhai, R. Slade, S. Connors, R. van Diemen, M. Ferrat, E. Haughey, S. Luz, S. Neogi, M. Pathak, J. Petzold, J. Portugal Pereira, P. Vyas, E. Huntley, K. Kissick, M. Belkacemi, J. Malley, (eds.)]. In press. 
Iwaro, J., \& Mwasha, A. (2010). A review of building energy regulation and policy for energy conservation in developing countries. [Online]. Available from:

https://www.researchgate.net/publication/227415222_A_review_of_building_energy_regulati on_and_policy_for_energy_conservation_in_developing_countries. [Accessed May 14 2021].

Laubscher, J. (2011). PhD Thesis: An investigation of the National Building Regulations to promote uniformity and sustainability in the South African built environment. Pretoria: University of Pretoria.

Liang, W., Shi, Y., Zhang, H., Yue, J., \& Huang, G. H, (2007). Greenhouse Gas Emissions from Northeast China Rice Fields in Fallow Season. Pedosphere. 17. [Online]. Available from: https://www.sciencedirect.com/science/article/pii/S1002016007600757. [Accessed 16 February 2021].

Lombard, L.P., Jose, O., \& Christine, P. (2008). A review on buildings energy consumption information. Energy and Building, 40 (3), 394-398.

Opperman, R.W. (2011). Workshop: Implementation and impact of the new National Building Regulations. Pretoria, PIA: NRCS.

SABS. (2011a). SANS 204:2011. South African National Standard: Energy efficiency in buildings. Edition 1. Pretoria: SABS.

SABS. (2011b). SANS 10400 XA. South African National Standard: Energy usage in buildings. Edition 1. Pretoria: SABS.

Saidur, R. (2009). Energy consumption, energy savings, and emission analysis in Malaysian office buildings. Energy Policy, 37, 4104-4113

Smith, A. K., Ayanian, J. Z., Covinsky, K. E., Landon, B. E., McCarthy, E. P., wee, C. C., \& Steinman, M. A. (2011). Conducting high-value secondary dataset analysis: An introductory guide and resources. Journal of General Internal Medicine, 28(8), pp. 920- 929.

Smith, E. (2008). Using secondary data in educational and social research. New York, NY: McGrawHill Education.

Tricker, R., \& Algar, R. (2006). Building Regulations in Brief. 4th ed. Amsterdam: Elsevier BH. 
UNDESA. (2019). United Nations Department of Economic and Social Affairs. World Population Prospects 2019: Highlights. United Nations, Department of Economic and Social Affairs, Population Division.

UNEP SBCI. (2009). Buildings and Climate Change: Summary for Decision-Makers. Paris: United Nations Environment Programme.

UNEP. (2009a). United Nations Environmental Programme: Assessment of policy instruments for reducing greenhouse gas emissions. [Online]. Available from: /http://www.unep.org/sbci/pdfs/SBCI_CEU_Policy_Tool_Report./cited2009S. [Accessed 26 January 2021].

UNEP. (2009b). Assessment of policy instruments for reducing greenhouse gas emissions from buildings. [Online]. Available from: /http://www.unep.org/themes/consumption/pdf/SBCI_CEU_Policy_Tool_Report/cited2009S. [Accessed 26 January 2021].

UNEP. (2020). 2020 Global Status Report for Buildings and Construction: Towards a Zero-emission, Efficient and Resilient Buildings and Construction Sector. Nairobi. [Online]. Available from: https://globalabc.org/sites/default/files/inlinefiles/2020\%20Buildings\%20GSR_FULL\%20REPORT.pdf. [Accessed 15 January 2021].

UNFCCC. (2016). United Nations Framework Convention on Climate change: Report of the Conference of the Parties on its twenty-first session, held in Paris from 30 November to 13 December 2015: FCCC/CP/2015/10. [Bonn], United Nations FCCC.

Watermeyer, R.B. (2003). Performance-based building regulations and their usage in South Africa. Civil Engineering Sivili Enjeneereng, 11(2), pp. 6-8.

Winkler, H. (2006). Energy policies for sustainable development in South Africa's residential and electricity sectors: Implications for mitigating climate change. $\mathrm{PhD}$ thesis. Cape Town: University of Cape Town. 